\title{
Myelosclerosis associated with systemic lupus erythematosus in patients in West Malaysia
}

\author{
K. S. LAU AND J. C. White \\ From the Department of Pathology, Faculty of Medicine, University of Malaya, \\ Kuala Lumpur
}

SYNOPSIS Three cases of myelosclerosis associated with systemic lupus erythematosus are described. The probable role of systemic lupus erythematosus in the initiation of myelonecrosis and subsequent myelosclerosis is discussed.

Both myelosclerosis and systemic lupus erythematosus are not uncommon conditions in West Malaysia. However, their association in a patient is a rare occurrence and is referred to only indirectly in the literature (Burkhardt, 1965). We have recently encountered three cases in South Indian subjects in Selangor. In one of these, particularly, the evidence suggests that the systemic lupus erythematosus is the causative pathogenetic factor in the development of myelosclerosis.

\section{CASE REPORTS}

CASE 1 The first patient is a 70-year-old man with a history of alcoholism, and of poor social and economic status. The legs and abdomen had been swollen for two years. The enlarged spleen extended to the umbilicus, the liver was firm and palpable $5 \mathrm{~cm}$ below the costal margin, and ascites was present. There was proteinuria, with epithelial cells only in the deposit. Blood pressure was $120 / 65 \mathrm{~mm} \mathrm{Hg}$. He had moderate anaemia and a leucoerythroblastic blood picture with poikilocytosis. The average $\mathrm{Hb}$ was $9 \mathrm{~g} / 100 \mathrm{ml}, \mathrm{MCHC} 32 \%$, WBC 30,000/ $\mu \mathrm{l}$ (myeloblasts 1,200 , erythroblasts 120 ), platelets $97,000 /$ $\mu \mathrm{l}$, reticulocytes $3 \%$. Serum assays gave iron $90 \mu \mathrm{g} / 100 \mathrm{ml}$, TIBC $191 \mu \mathrm{g} / 100 \mathrm{ml}$, folate $6.2 \mathrm{ng} / \mathrm{ml}, B_{12} 268 \mathrm{pg} / \mathrm{ml}$, $\mathrm{UB}_{12} \mathrm{BC} 9,118 \mathrm{pg} / \mathrm{ml}$. The average value for leucocyte alkaline phosphatase was 185 . The direct and indirect Coombs tests were negative. The total serum protein level was $7 \cdot 7 \mathrm{~g} / 100 \mathrm{ml}$, with a low albumin $(2 \cdot 8 \mathrm{~g} / 100 \mathrm{ml})$ and raised $\gamma$-globulin $(2.8 \mathrm{~g} / 100 \mathrm{ml})$. The erythrocyte sedimentation rate was $30 \mathrm{~mm} /$ hour. The sternal marrow aspirate showed scanty, poorly cellular material with $5.5 \%$ myeloblasts, $6.5 \%$ ghost reticulum cells, and tags of dense sclerotic tissue. The Turkel and Bethell needle trephine biopsy of the iliac crest indicated extensive myelofibrosis, with reticulin and collagen fibrils in excess, and osteosclerosis (Fig. 1). There was marked

Received for publication 30 October 1968. reduction of haemopoietic tissue but active proliferation of primitive reticulum and blast cells. Haemosiderin iron was scanty.

During the course of his period in hospital the patient developed a chest infection with left pleural effusion. The aspirated pleural fluid was bloodstained, containing $\mathbf{7 5 0}$ leucocytes per $\mu \mathrm{l}$. The cells were predominantly adult and primitive granulocytes, and numerous typical LE cells were present (Fig. 2). No microorganisms were seen. The LE test then performed on the peripheral blood was positive, 1 per 1,000 leucocytes, with occasional haematoxylin bodies. The infection subsided with antibiotic therapy, but at this point the patient discharged himself

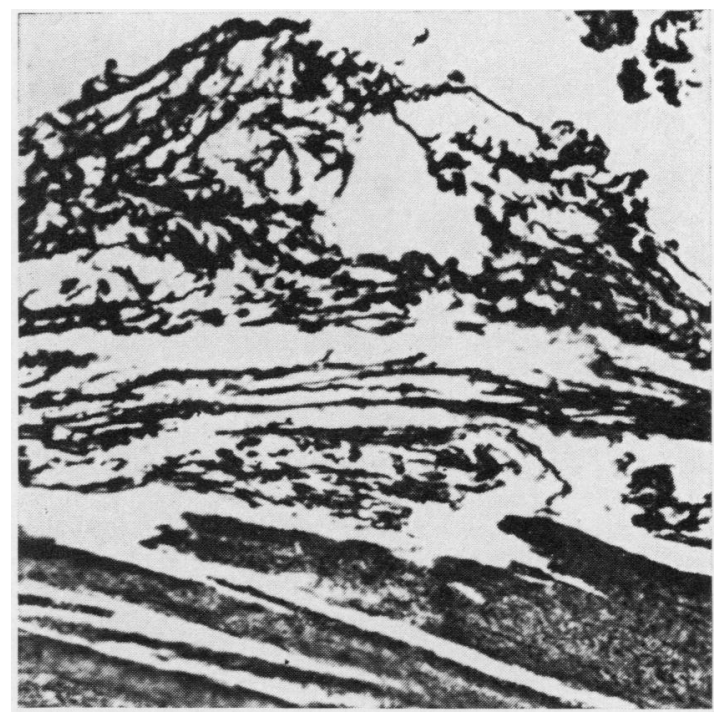

FIG. 1. Needle trephine biopsy section of iliac crest marrow of case 1 showing excess coarse reticulin formation in stroma and osteosclerosis. Silver impregnation. $\times 260$. 


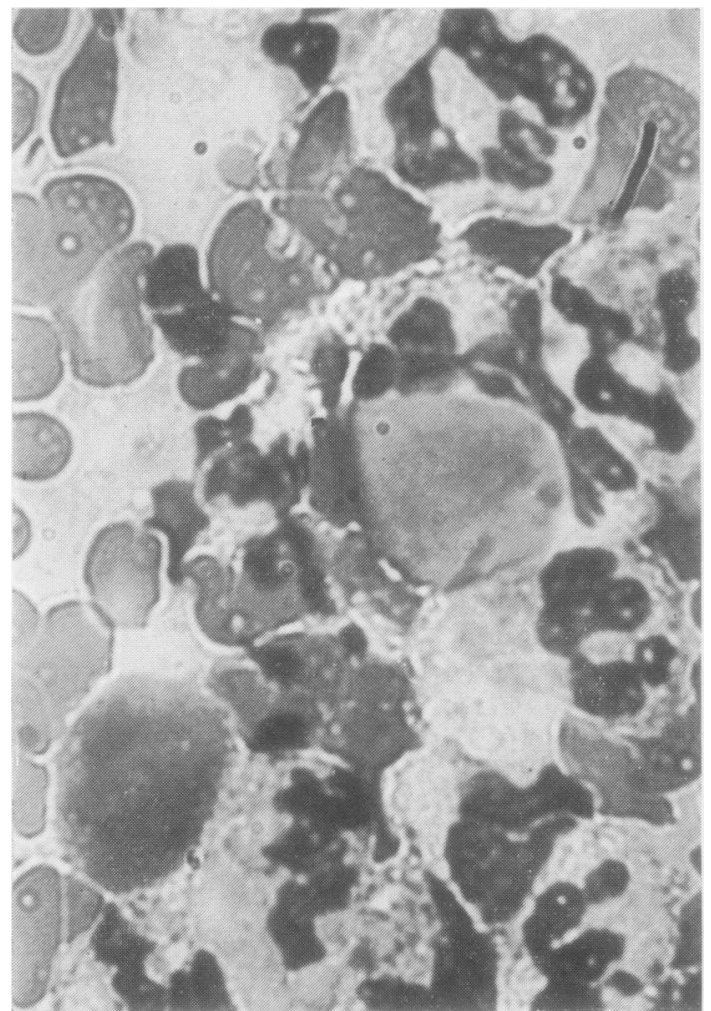

FIG. 2. LE cell and haematoxylin body in film of cellular deposit from aspirated pleural fluid from case 1. MayGrünwald-Giemsa stain. $\times 900$.

from hospital. He has since died, but no postmortem examination was obtainable.

CASE 2 This patient is an unemployed South Indian man of 54 years, living in poor circumstances in a rural area. Productive cough and shortness of breath on exertion had been present for one year with intermittent asthmatic attacks and evidence of widespread emphysema and bronchitis. He has had no rash or joint or bone pains. The liver and spleen were not palpable. Blood pressure was $130 / 90 \mathrm{~mm} \mathrm{Hg}$. The average value for $\mathrm{Hb}$ was $12 \cdot 2 \mathrm{~g} / 100 \mathrm{ml}, \mathrm{MCHC} 33 \%$, WBC $7,000 / \mu \mathrm{l}$ (eosinophils 7 to $23 \%$ ), platelets $175,000 / \mu 1$, reticulocytes $0 \cdot 1 \%$. In the blood film there was slight anisocytosis and anischromasia of red cells, a good deal of rouleaux formation and dark-staining 'high globulin' background. There were no immature cells. The average value for the erythrocyte sedimentation rate was $93 \mathrm{~mm} /$ hour. The direct Coombs test was negative.

The urine showed persistent proteinuria $(0.8 \mathrm{~g} / 24 \mathrm{hr})$ and a positive test for Bence-Jones protein, but no casts. The total serum protein level was $7.5 \mathrm{~g} / 100 \mathrm{ml}$, with slightly lowered albumin, $3.2 \mathrm{~g} / 100 \mathrm{ml}$. The $\gamma$-globulin level was normal, $1.3 \mathrm{~g} / 100 \mathrm{ml}$, but the levels of $a_{2}$ -globulin, $1 \cdot 2 \mathrm{~g} / 100 \mathrm{ml}$, and of $\beta_{2}$-globulin, $1.35 \mathrm{~g} / 100 \mathrm{ml}$,

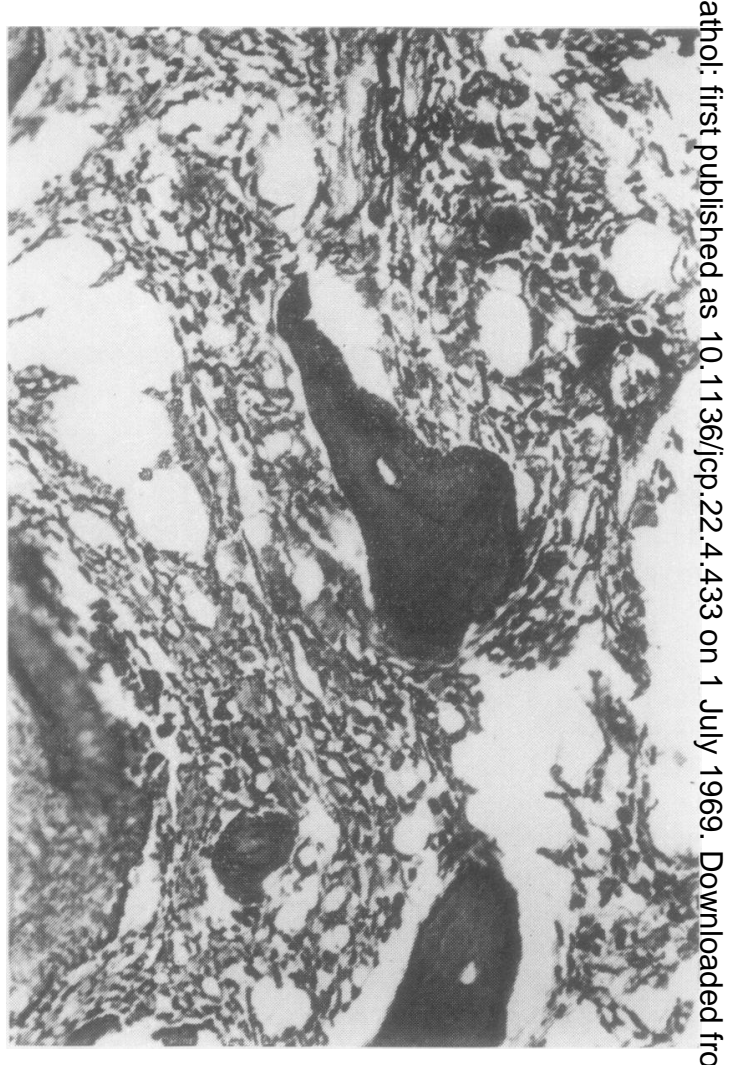

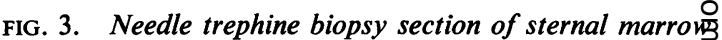
from case 2 showing coarse and fine reticulin fibril forma담 tion. Silver impregnation. $\times 150$.

were both raised. The LE cell test on two occasions showed haematoxylin bodies, 1 per 2,000 leucocytes? In the first preparation typical stage I and II nuclear. changes were seen in 1 per 1,000 polymorphs, and in the second, characteristic LE cells were present in 1 peß 1,500 leucocytes (Miescher, Rothfield, and Mieschero 1966). There was radiological evidence of decalcification of lumbar vertebral bodies with partial collapse of the bodies of $\mathrm{D} 11$ and 12 and to a slight extent of $\mathrm{L} 2$; the. skull was normal. Myelomatosis was considered, buf bone marrow investigation failed to establish this diagnosis and indicated an active myelosclerotic process The patient's main disability remained the chest condie tion.

Bone marrow biopsy Sternal puncture provided rather poorly cellular marrow, and the plasma cells presen were active but morphologically normal and formed less than $1 \%$ of the total nucleated cells. Some giant cells and reticulum cells were seen. However, a number of tags of densely staining amorphous and fibrous material were present as well as fatty areas and pools of dark-stainin? protein background material. Subsequent needle trephing biopsy of the sternum provided sections and further films. The films showed diminished normoblastic erythro@ 
poiesis and granulopoiesis as before. The rolymorphs often had prominent, reddish-staining granules with MayGrünwald-Giemsa stain, and the score of alkaline phosphatase activity was high at 182 . Plasma cells were very scanty. The frequent sclerotic tags gave a strong PAS reaction and diffuse lilac-red staining with pyroninmethyl green. The positive Feulgen reaction indicated that DNA was widely dispersed throughout the tags or interspersed with protein retaining the acidic light green counterstain. Haemosiderin iron was not present in excess.

The histological sections of the decalcified biopsy showed bony overgrowth and marked reduction of cellular stromal marrow. In the denser and more cellular areas, fine collagen fibrils were notable, and the cell nuclei included degenerate forms and occasional haematoxylin bodies. Adjacent areas were poorly cellular, with an abnormal stromal ground structure of fibrillary and coarsely reticular material. Elongated particles of fibrinoid material were seen in these areas, staining deep red with the MSB stain of Lendrum, Fraser, Slidders, and Henderson (1962). Silver impregnation showed a network of coarse spiral reticulin fibrils throughout, but particularly around vessels and sinusoids, and with exceedingly delicate silver-impregnated fibrils forming parallel arrays and networks between them (Fig. 3).

CASE 3 The patient was a young South Indian woman of 25 years, a former school teacher. She had a history for one year of rash, fever, swollen joints, and weakness, together with a moderately severe anaemia. There was a history of possible pencillin sensitivity. Throughout the year she had been on courses of steroids for treatment of systemic lupus erythematosus at a district hospital. On presentation at the University Hospital she had minimal hepatosplenomegaly. The haemoglobin level was $8.3 \mathrm{~g} / 100 \mathrm{ml}$, MCHC $32 \%$, reticulocytes $1 \%$. Serum assays gave iron $33 \mu \mathrm{g} / 100 \mathrm{ml}$, TIBC $228 \mu \mathrm{g} / 100 \mathrm{ml}$, folate $10 \mathrm{ng} / \mathrm{ml}, B_{12} 159 \mathrm{pg} / \mathrm{ml}, \mathrm{UB}_{12} B C 2,880 \mathrm{pg} / \mathrm{ml}$. She had a leucopenia of $2,700 / \mu 1$, thrombocytopenia of $26,000 / \mu 1$, and a leucoerythroblastic picture with occasionalmyelocytes and erythroblasts, poikilocytes, and elliptocytes. The direct and indirect Coombs tests were negative; total serum protein was $6.8 \mathrm{~g} / 100 \mathrm{ml}$, with a low albumin level, $1.7 \mathrm{~g} / 100 \mathrm{ml}$, and a raised $\gamma$-globulin level, $2.4 \mathrm{~g} / 100 \mathrm{ml}$. The erythrocyte sedimentation rate ranged from 110 to $120 \mathrm{~mm} /$ hour. The LE test was

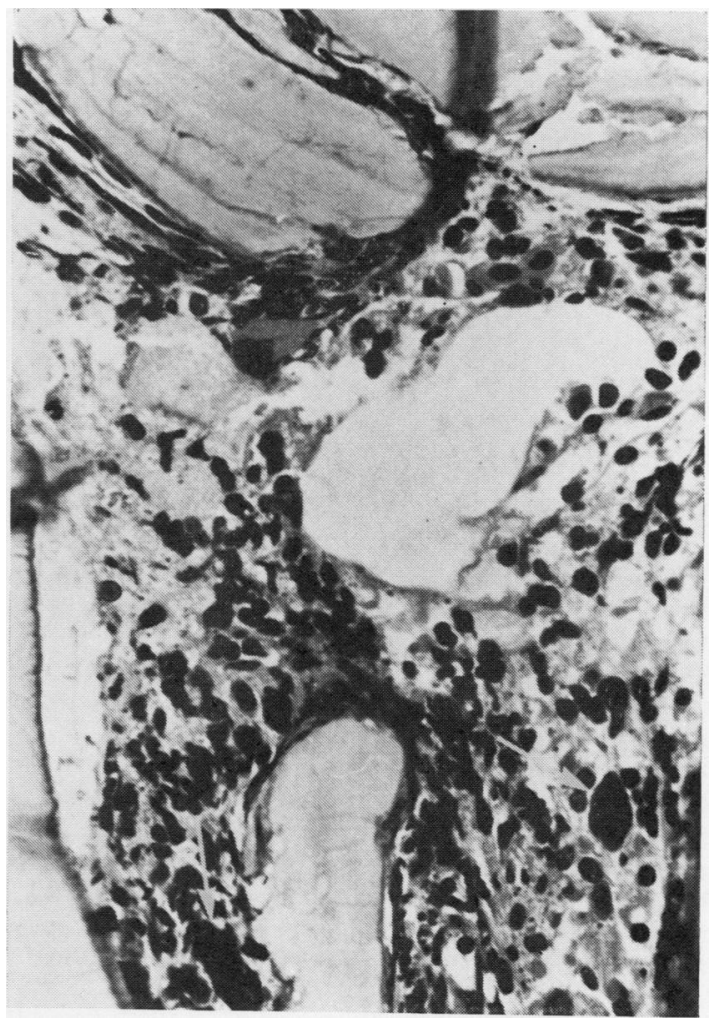

FIG. 5
FIG. 4

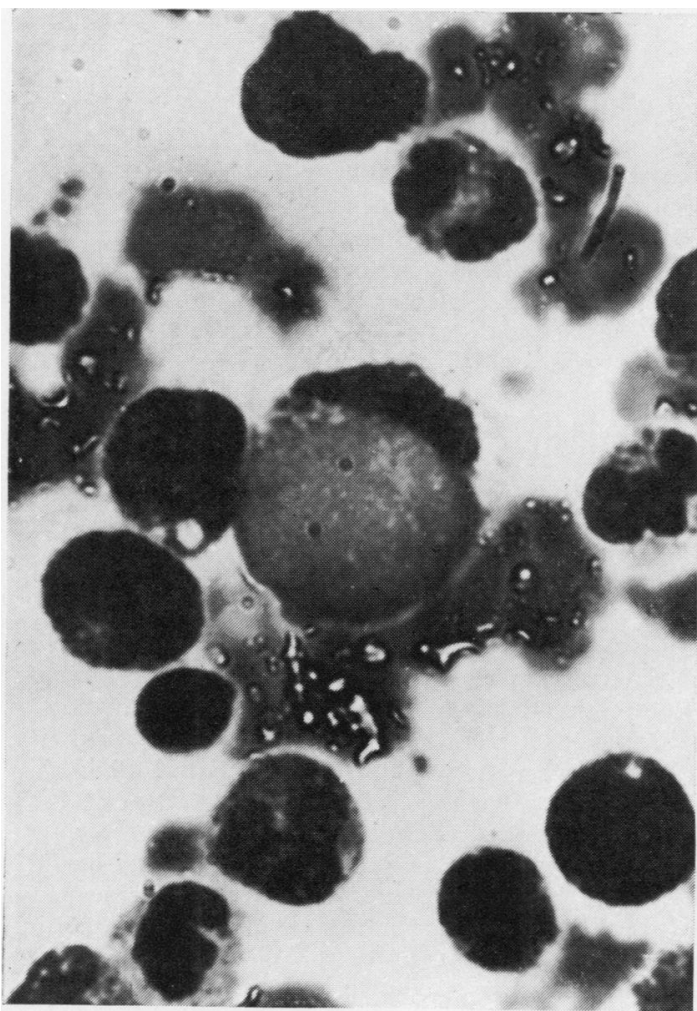

FIG. 4. LE cell preparation from peripheral blood of case 3. May-Grünwald-Giemsa stain. $\times 900$.

FIG. 5. Needle trephine biopsy section of sternal marrow of case 3 showing haematoxylin bodies, stromal necrosis and early fibrosis, and osteosclerosis. Haematoxylin and eosin. $\times 260$. 


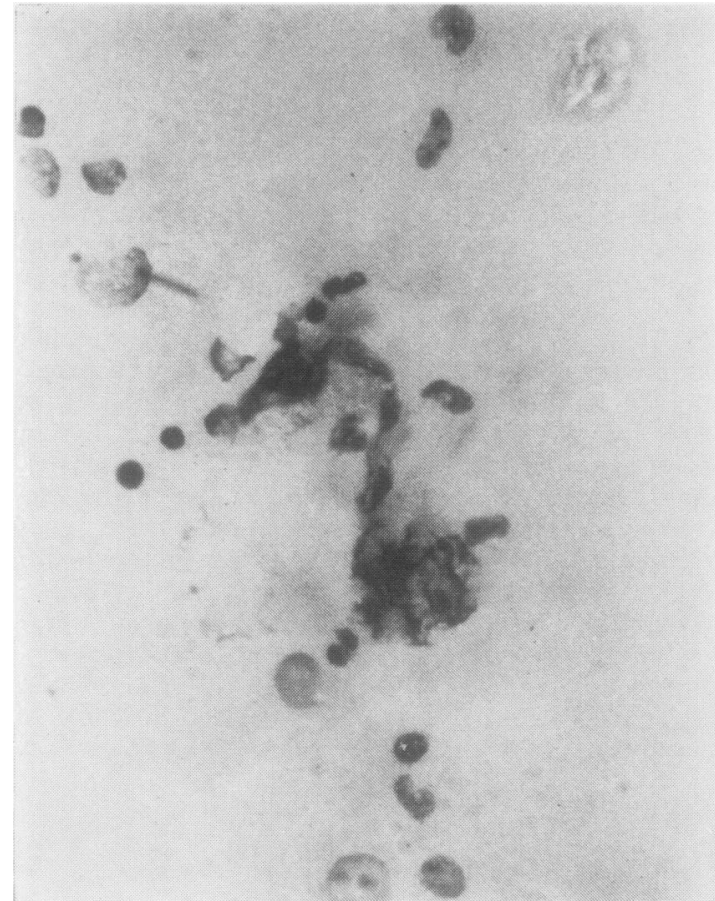

FIG. 6

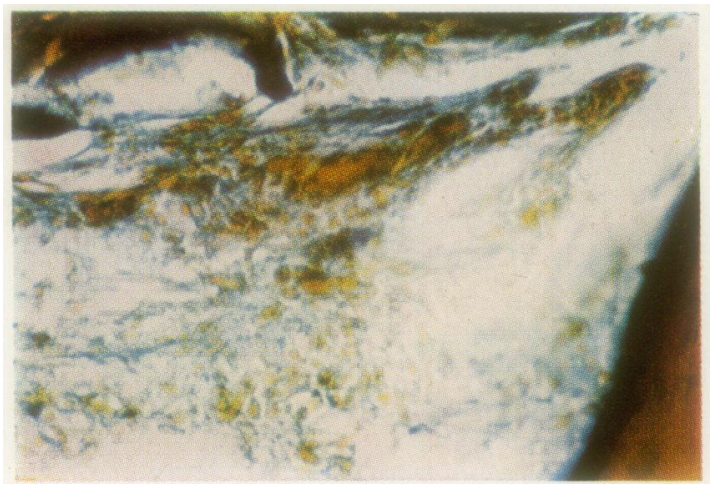

FIG. 8

FIG. 6. Feulgen-positive mass in film from sternal marrow aspirate in case 3. The Feulgen-positive material is interspersed with and diffused into acidophilic protein (light green counterstain). The surrounding cells are intact. $\times 260$.

FIG. 7. Fibrous tag from sternal marrow film of case 3 showing haemosiderin masses embedded in ground substance with hyaline and fibrillary elements. Perl's stain with saffranin counterstain. $\times 900$.

FIG. 8. Needle trephine biopsy section of sternal marrow of case 3 stained with aniline blue 707 and orange $G$ at $\mathrm{pH}$ 3. Elongated masses of basic protein (orange stained) with surrounding fibrillary and hyaline stromal ground substance (blue stained), as well as intact (orange stained) nuclei. $\times 260$.

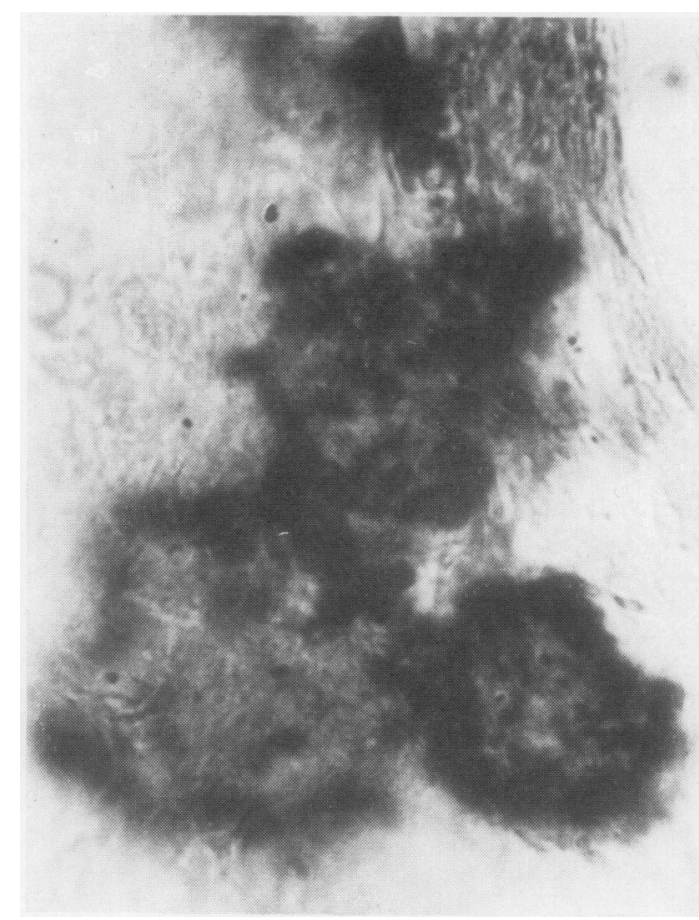

FIG. 7

repeatedly positive $(1: 10,000)$, with occasional haematoxylin bodies and rosettes (Fig. 4).

Bone marrow biopsy Sternal and iliac crest marrow $\vec{F}$ punctures provided a scanty aspirate with poor cellular-윽 ity and reduced haemopoiesis; erythropoiesis was partly megaloblastiform. Reticulum cells were present together with rounded or irregular masses of degenerate cellular and fibrous material. A needle trephine biopsy응 of the sternum showed active myelosclerosis with in-: creased osteosclerosis and moderately increased re- $\frac{3}{3}$ ticulin, together with a well marked necrotic element (Fig. 5).

Haematoxylin bodies were present in the sections (Fig. 5) and appeared as rounded and irregular masses in음 the films. Giant cells were frequently but by no means $D$ exclusively involved in the degenerative changes. The Feulgen reaction showed DNA interspersed with, and diffused into, acidophilic protein (Fig. 6). There was 0 diffuse lilac-red staining with pyronin-methyl green. Then irregular tags seen in the films had partly hyaline, partly microfibrillary structure, and gave a positive PAS reaction. They often enclosed nuclear debris, and much haemosiderin iron was present (Fig. 7). Aniline blue 7070 and orange $\mathrm{G}$ at $p \mathrm{H} 3$ were used after Susa fixation to distinguish highly basic (orange G-retaining) from other $\stackrel{\infty}{+}$ (aniline-blue-retaining) proteins (White, 1950). These $\square$ basic proteins were present in and around the Feulgen- $\overline{0}$ positive areas, forming bulky masses surrounding DNA $\overrightarrow{\mathbb{\Phi}}$ in both films and sections (Fig. 8). The fibrillary and $\frac{\rho}{\mathbb{D}}$ hyaline stromal ground material retained aniline blue $\mathrm{e}$ (Fig. 8), and there was only patchy retention of fibrino stains (Lendrum et al, 1962). 


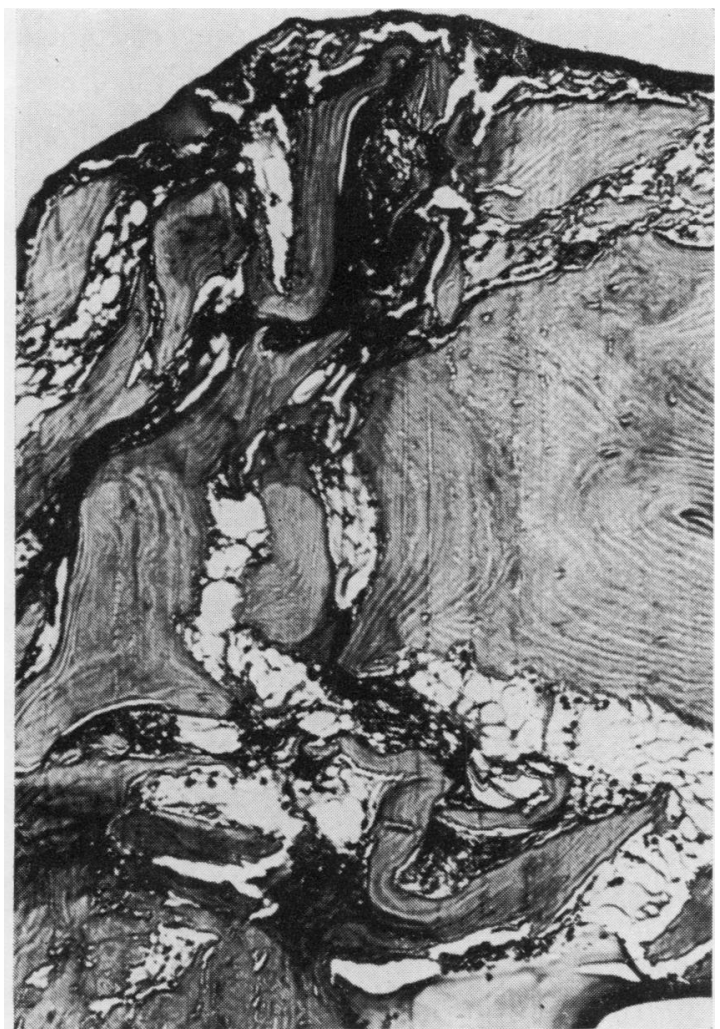

FIG. 9. Follow-up biopsy on sternal marrow of case 3 showing advanced sclerosis, fatty hypoplasia, and bony overgrowth. Martius-Scarlet-Blue stain. $\times 65$.

Over the last three months the patient's blood picture has improved $(\mathrm{Hb} 10.8 \mathrm{~g} / 100 \mathrm{ml}$, leucocytes and platelets normal) under continued steroid therapy. The $\mathrm{Hb}$ level has stabilized at about $10 \mathrm{~g} / 100 \mathrm{ml}$, and the leucocytes and platelets are normal. The serum proteins are more normal. The LE test became negative but has been found to revert to positive on reduction of steroid dosage. The sedimentation rate remains high, 70 to $80 \mathrm{~mm} /$ hour.

However, a further needle trephine biopsy shows that the marrow structure remains abnormal as before, with all degrees of damage from active necrosis in cellular areas to zones of advanced sclerosis and fatty hypoplasia surrounded by bony overgrowth (Fig. 9). Recently discoid lesions have recurred with attempts to reduce the dosage of steroids, but these have now subsided.

Proteinuria has been present throughout the illness at a level of about $25 \mathrm{mg} / 100 \mathrm{ml}$, and with occasional hyaline and granular casts in the deposit. The blood pressure has remained normal.

\section{DISCUSSION}

In the first case described the myelosclerosis was well established and appeared to be a chronic process, with excess reticulin and fibrous elements (Fig. 1). The LE cells were discovered as an apparently in vivo phenomenon through the immediate emergency examination of the pleural exudate. Systemic lupus erythematosus was not suspected in the second patient on presentation. He is not as yet anaemic, in spite of the severe damage demonstrated in the bone marrow. The marrow examination also excluded myelomatosis, and it is recognized that BenceJones proteinuria may occur in systemic lupus erythematosus (Epstein and Tan, 1964).

Neither of the two preceding patients presented with the classical features of systemic lupus erythematosus. The third patient is the youngest and a female. In her case typical systemic lupus erythematosus had been apparent for about a year before the diagnosis of myelosclerosis was established. In this instance the necrotic element in the myelosclerosis was much more evident, together with advancing reticulin formation and bony overgrowth (Fig. 5). Peace (1953) has produced considerable histological evidence for the significance of necrosis as an important phase in the development of myelosclerosis, and he considers myeloproliferative syndromes to be 'variations of general mesenchymal reaction to several types of injury with myelonecrosis best describing the histopathological lesions'. We are in accord with this view and regard the finding of myelosclerosis in association with systemic lupus erythematosus as an uncommon but well defined reaction of the haemopoietic mesenchymal tissues to this autoimmune process. The mesenchymal origin of haematoxylin bodies has been particularly stressed (Klemperer, Gueft, Lee, Leuchtenberger, and Pollister, 1950). In the instance of focal necrosis in renal glomerular tufts in systemic lupus erythematosus, the association of these bodies with the hyaline protein material has been related at least in part to degradation of nucleoprotein (Klemperer et al, 1950; Gueft and Laufer, 1954; Smith, 1955).

The coexistence of haematoxylin bodies and damaged stromal ground structure is particularly striking in the second of the two cases we describe, with extension of nuclear constituents into the fibrillary structure of the damaged stroma. Although nuclear damage through thixotropy can arise in biopsy specimens (Armstrong and White, 1950), this seems unlikely to account for the nuclear damage described. This is not present in biopsy sections of myelosclerosis without systemic lupus erythematosus, in spite of extensive stromal changes. Further, these established changes are quite unlike the classical LE cell phenomenon observed in marrow films (Hargraves, Richmond, and Morton, 1948).

In systemic lupus erythematosus the formation of 
the nuclear bodies would appear to be the primary event, with subsequent changes in amount, distribution, and nature of proteins both in situ and in the surrounding tissues (Godman, Deitch, and Klemperer, 1958). In the special situation of myelosclerosis occurring in association with systemic lupus erythematosus, similar considerations appear to apply.

Basic protein is clearly abundant in the area of the nuclear bodies (Figs. 6 and 8 ) and the observed orange G-binding is characteristic of histone in normal nuclei (White, 1950). Structural considerations would suggest that the basic protein is in fact histone, although its physical state may be altered. However, Godman et al (1958) have produced evidence that histone is actually lost in this situation and replaced by a large influx of other basic protein although the true nature of such protein remains unknown.

There is considerable evidence for the heterogeneous composition of the protein deposits seen in the sites of damage in systemic lupus erythematosus, and $\gamma$-globulin and complement deposited in antigenantibody precipitates are present (Vazquez and Dixon, 1957; Mellors, Ortega, and Holman, 1957; Lachmann, Müller-Eberhard, Kunkel, and Paronetto, 1962), as well as the damaged nuclear protein discussed above and damaged ground substance. An organized lattice structure has been demonstrated by electron microscopy in parts of the extracellular deposits in lupus nephritis and it has been suggested that these may have been built up from parallel long-range membranous structures with periodicities ranging from 50 to $250 \AA$ (Grishman, Porush, Rosen, and Churg, 1966).

The work of Burkhardt (1965) on the lightmicroscopic fine structure of the bone marrow in systemic lupus erythematosus drew attention clearly to widespread but variable damage to marrow, and in particular to damage to ground substance around blood vessels and sinusoids. The third case we describe illustrates the full range of consequences of myelonecrosis, ranging from fatty change to extremes of sclerosis. Although vascular changes were present they were not as striking as those in Burkhardt's examples, but stromal necrosis was the main feature with marked changes in the fibrillary ground substance. In the first case the myelosclerosis was well advanced in the terminal illness, and it is not possible to determine whether the systemic lupus erythematosus preceded or followed this.

The occasional occurrence of frank myelosclerosis in systemic lupus erythematosus might well be an extension of the basic lesions of this condition, with the bone marrow as the target organ. The changes considered by Burkhardt to be common in the marrow in systemic lupus erythematosus would 을 thus lead directly to development of the anaemia. However, in five other cases of the condition associated with anaemia, including the autoimmune haemolytic type, we have found no significant evidence of altered integrity of the basic bone marrow structure or evidence of haematoxylin bodies. Conversely, in two cases of myelosclerosis with a negative LE cell test the changes associated with $\vec{\circ}$ nuclear damage were not seen in the marrow preparations.

This work was supported in part by funds from the US Public Health Service Asia grant no. AM11048-01. We wish to thank Mr Chan Gim Leong, Mr N. A. Nathan, and Mr Yee Kwok Hoi for technical assistance.

\section{ADDENDUM}

Since submitting this paper we have encountered a

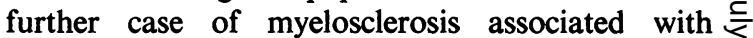
systemic lupus erythematosus, again occurring in a young south Indian woman aged 19. The systemic lupus erythematosus is typical and florid, with a strongly positive LE cell test $(1: 200)$. She has anaemia and the characteristic features of necrotic and sclerotic changes in the bone marrow described above. A special feature in the peripheral blood film is the presence of 'tadpole-shaped' poikilocytes in addition to tear-drop forms. Her response to steroid therapy has been definite but slow, and the LE cell test remains positive. As in case 3, the evolution of this patient's illness suggests that the myelosclerosis is a consequence of systemic lupus erythematosus.

\section{REFERENCES}

Armstrong, J. B., and White, J. C. (1950). Lancet, 2, 739.

Burkhardt, R. (1965). Seminars Hemat., 2, 29.

Epstein, W. V., and Tan, M. (1964). Arthr. and Rheum., 7, 733. Godman, G. C., Deitch, A. D., and Klemperer, P. (1958). Amer. J. Path., 34, 1.

Grishman, E. Porush, J. G., Rosen, S. M., and Churg, J. (1966). In Sixth International Congress for Electron Microscopy, Kyoto, O edited by R. Ueda, p. 747. Maruzen Co. Ltd, Tokyo.

Gueft, B., and Laufer, A. (1954). Arch. Path., 57, 201

Hargraves, M. M., Richmond, H., and Morton, R. (1948). Proc. Mayo Clin., 23, 25.

Klemperer, P., Gueft, B., Lee, S. L., Leuchtenberger, C., and Pollister, $O$ A.W. (1950). Arch. Path., 49, 503.

Lachmann, P. J., Müller-Eberhard, H. J., Kunkel, H. G., and Paronetto, F. (1962). J. exp. Med., 115, 63.

Lendrum, A. C., Fraser, D. S.. Slidders, W., and Henderson, R. (1962). \& J. clin. Path., 15, 401.

Mellors, R. C., Ortega, L. G., and Holman, H. R. (1957). J. exp. Med., 106, 191.

Miescher, P. A., Rothfield, N., and Miescher, E. (1966). In Lupus Erythematosus, edited by E. L. Du Bois, p. 93. McGraw-Hill, New York and London.

Peace, R. J. (1953). Amer. J. Path., 29, 1029.

Smith J. F. (1955). J. Path. Bact., 70, 41

Vazquez, J. J. and Dixon, F. J. (1957). Lab. Invest., 6, 205.

White, J. C. (1950). Biochem. J., 46, 24P. 